\title{
A Review on Mycosynthesis, Mechanism, and Characterization of Silver and Gold Nanoparticles
}

\author{
Kangkana Banerjee $^{1}$ • V. Ravishankar Rai ${ }^{1}$
}

Published online: 10 August 2017

(C) Springer Science+Business Media, LLC 2017, Corrected publication September/2017

\begin{abstract}
The study on green synthesis methods and on its potential applications for the mankind are in trend over 10 or more decades in the field of bioscience. A significant number of works have been done on the synthesis of nanoparticles by a microorganism which clearly shows the reliability of this method. Microbes can be used for synthesis process at much lower cost and in an environment-friendly approach. Among microbes, fungi can be mass grown in vitro, and they demonstrate an easy downstream processing for nanoparticles. Biosynthesized nanoparticles are the by-product of their resistance mechanism of the metal concerned, in different sizes and shapes. Also, presently, there are various methods of characterizing the metal nanoparticles. In this review, we will analyze aspects of mycosynthesis of silver and gold nanoparticles and their different characterization techniques. We are intended to give a clear picture of the importance and downside of this method.
\end{abstract}

Keywords Mycosynthesis · Silver nanoparticles (AgNPs) · Gold nanoparticles (AuNPs) $\cdot$ Mechanism $\cdot$ Downstream process

\section{Introduction}

Nanostructured particles ranging from 1 to $1000 \mathrm{~nm}$ in size are well-known for creating wonders in the field of

The original version of this article was revised: There were errors in Figures 2, 3 and 4 in the original publication of the article. The 3 figures were interchanged.

V. Ravishankar Rai

raivittal@gmail.com

1 Department of Studies in Microbiology, University of Mysore, Manasagangothri, Mysore, Karnataka 570006, India nanobiotechnology in recent years. Bioscience studies have revealed that natural mechanisms in microorganisms like bioaccumulation, biomineralization, precipitation, and biosorption against toxic compounds lead to synthesis and design of these particles. The simple detoxifying process in microbes is solely responsible for the synthesis of nanoparticles and termed as nanobiosynthesis. This, according to Siddiqi and Husen [1], is the most benign and inexpensive route so far. Whereas, chemical and physical syntheses are always considered hazardous and costly that make them disadvantageous. Furthermore, drawbacks of using chemicals in synthesis processes include their interference in biomedical functions. The toxic chemicals get absorbed on surfaces of the particles resulting in undesirable effect during their use in medical applications. Also, it is comparatively easier to control the shapes and sizes of the particles for certain pharmaceutical and therapeutic purposes as desired. Though plants as well can be extensively used in preparing nanoparticles, the most preferred route is the microbial synthesis since it is undoubtedly eco-friendly, cost-effective, manipulative, and compatible with any kind of biomedical research [2].

The microbial processes utilize extracts from different species of bacteria, fungi, actinomycetes, algae, etc. for nanoparticle synthesis [3]. However, fungi are the most ideal among all microorganisms given that it allows a higher level of productivity due to its ability to secrete higher amount of proteins [4]. Also, the presence of mycelia provides them with a larger surface area, and they are economically reasonable as well as easy to grow. Besides, they show considerably simple downstream processing during synthesis. In case of many fungi, it is known to be NADH-dependent reductase enzyme that is responsible for the reduction of metals, whereas, in others, it is various types of proteins, organic acids, polysaccharides, glucose, etc. [5-8].

The present trend in bio-nanoscience involves the synthesis of especially metal nanoparticles because of their varied range 
of applications in the field of biology, chemistry, and physics. Among different metals that have been studied for their importance, silver and gold showed maximum use in biological applications. They are incredibly considered as antimicrobials, antioxidants, catalysts, anticancerous, and so on [1, 9-15]. Silver and gold NPs are therefore studied vastly over a period of time which led different research groups to biosynthesize and explore them tremendously. NPs are produced using extracts from several fungal species such as Penicillium citrinum [16], Aspergillus niger and Aspergillus parasiticus [17], Aspergillus flavus [18], Aspergillus concius, Penicillium janthinellum and Phomosis sp. [19], Pleurotus ostreatus [20], Aspergillus terreus [21], Bryophilous rhizoctonia [22], Fusarium oxysporum [23], and Fusarium semitectum [24]. Similarly, AuNPs are also synthesized by many such fungi namely, Aspergillus fumigates [25], Geobacillus sp. [26], and Aspergillus fischeri [13]. Besides fungi, yeasts are known best for their easy handling methods, with simple nutrient in the laboratory and therefore, are always chosen over bacteria for the nanoparticle synthesis. These eukaryotic systems, for example, Candida glabrata and Schizosaccharomyces pombe, are often used and had been reported in several kinds of literature [27]. Au-Ag alloy synthesized by yeast is also applied as various important aspects of these methods prove to produce a bulky number of metal nanoparticulate when compared to bacteria-mediated synthesis processes.

Once the metal particles are synthesized either randomly or as per desired properties, the next step is to characterize them. The distinctiveness of nanoparticles can be determined by special instruments working on different principles such as UV-visible spectrophotometer (UVVis spectra), X-ray diffractometer (XRD), dynamic light scattering (DLS), scanning and transmission electron microscopes (SEM and TEM), energy dispersive spectroscopy (EDS), and Fourier transform infrared (FT-IR) spectroscopy. These instruments are used to analyze the particles based on their size, shape, surface plasmon resonance (SPR), the charge on them, side groups present on them, and metallic characteristics $[28,29]$.

Hence, the review intends to give the readers an idea about the typical methods and means of biosynthesis of silver and gold nanoparticles carried out using different fungal species in the recent past. Also, we elaborate on the characterization methods and their principles which help recognize these particulates in the laboratory. This study on characterization of silver and gold nanoparticles will prove to be important for researchers to proceed in learning various mechanisms behind production processes and to plan any further experiments on the basis of synthesis routes. Characterization techniques help in an appropriate understanding of size, shape, side groups, and particle distribution or dispersity pattern of bionanoparticles which is significant in vital biomedical investigations involving silver and gold.

\section{Green Synthesis and Its Importance}

Green syntheses as the name suggests involve through and through the use of environmentally friendly and non-toxic means in synthesizing nanoparticles. Ganesan et al. [30] elaborated that unlike chemical and physical processes, these methods employ plants or microorganisms which are inexpensive, easily available, simple to grow, and safe to handle. Microbes have been vastly explored being easy to be cultured on Petri plates from different sources like soil, air, water, food and food crops, and plants on economical media. Use of high temperature, pressure, harsh reducing agents, organic solvents, and capping agents like sodium borohydride, chloroform, and toluene are common in the case of chemical and physical synthesis processes [16]. Such systems causing a hazard to the surroundings are undesirable for the environment. Also, in relevance to biomedical aspects, such harmful chemical might show side effects and interfere with the actual treatment practices. In context to human health, minimum risk is desired; thus, functions of metal nanoparticles in medical diagnostic imaging, pharmaceutical products, disease diagnostics, medical implants, wound dressing, and medical treatment protocols such as antimicrobials, antioxidants, antiinflammatory agents, anticancerous agents, and biological catalysts, are highly crucial. It was confirmed that biologically synthesized nanoparticles avoid such high possibilities of toxic problems [31]. Also, besides being eco-friendly and biocompatible, this path is a better way to achieve monodispersity and well-defined dimensions of the particles. Proteins or enzymes secreted by microorganisms or plants lead to the high productivity of comparatively superior quality nanoparticles [32]. The finer features help us create characteristic materials for specific applications, and they show the definite mode of action, which contributes to the advancement of various unknown research areas.

Many review articles have been published to describe different ways of biosynthesizing nanoparticles, especially microorganisms. Literature demonstrates how diverse group of metal nanoparticles as well as their alloys are biologically blended by bacteria, fungi, actinomycetes, and yeasts $[1,27$, 29, 33].

\subsection{Mechanism of Synthesis}

The mechanism behind green synthesis of nanoparticles has been studied very little so far. Different types of microorganisms show different techniques; however, the reduction reaction is the main principle behind all kinds of mechanisms (Fig. 1). Intracellular and extracellular routes are both seen taking place due to cellular peptides and polysaccharides which lead to enzymatic oxidation, reduction, sorption, and chelation. Intermembranous transport and consequent nucleation and growth of the nanoparticles lead to extracellular formations of 
Fig. 1 Mechanistic aspects of nanoparticle formation and stabilization

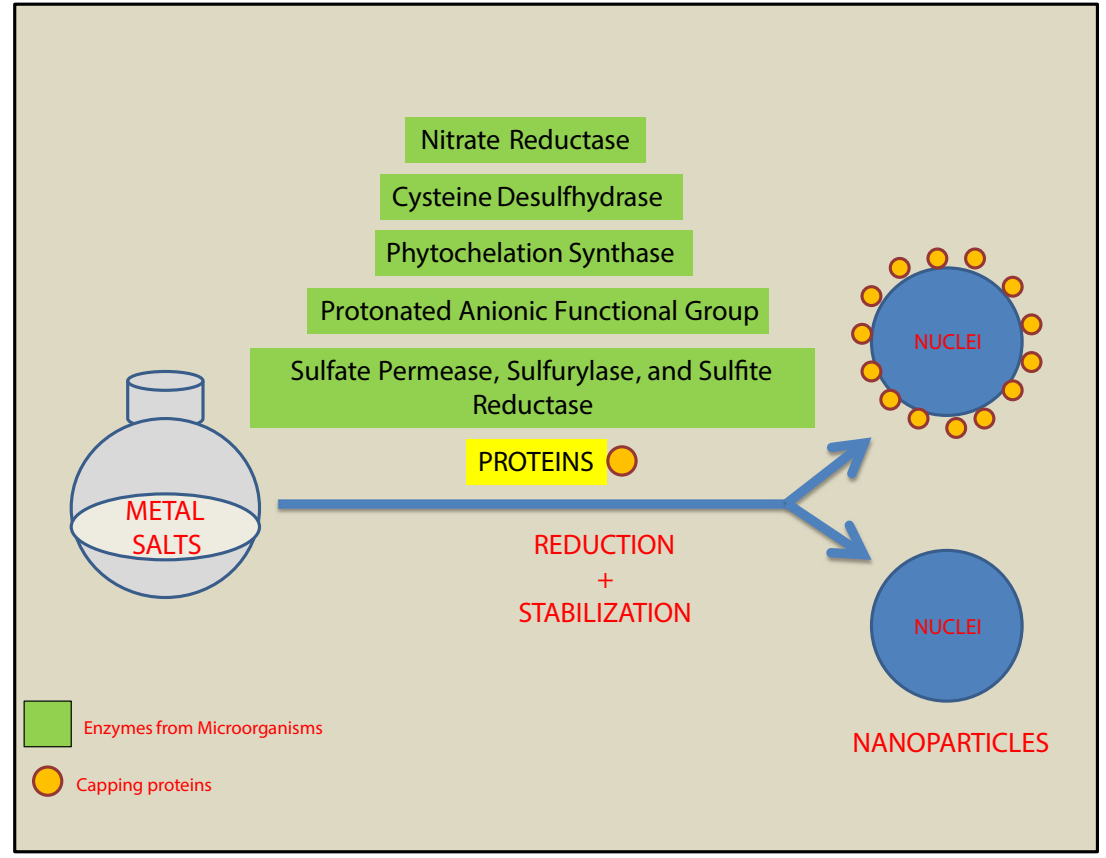

nanoparticles [32]. They also reported production of AgNPs using protonated anionic functional groups present on the cell wall of lactic acid bacteria. In the case of fungus, $F$. oxysporum, it is clearly explained how NADPH-dependent nitrate reductase enzyme reduces silver ions by transferring an electron to it with the help of NADP as co-factor. Also, it was explained that AgNPs are reduced by quinine derivatives of naphthoquinones and anthraquinones [34]. A similar process of reduction of gold ions $\left(\mathrm{Au}^{3+}\right)$ to $\mathrm{Au}^{0}$ is demonstrated using Stenotrophomonas maltophilia, a gram-negative bacterium [35]. Zinc sulfide ( $\mathrm{ZnS})$ nanoparticles were synthesized intracellularly by bacteria, Rhodobacter sphaeroides, by secreted enzymes like sulfate permease, sulfurylase, and sulfite reductase [36], again, cadmium sulfide (CdS) nanoparticles are produced extracellularly using a protein, cysteine desulfhydrase, secreted by Rhodopseudomonas palustris [37]. Extracellular process of synthesis of AgNPs is extensively elucidated using Verticillium sp. and $F$. oxysporum, where the silver ions are found to be get trapped on the fungal cell wall and reduced to silver nuclei by reductase enzyme present on the cell surface, ending in accumulation of these silver ions on the generated nuclei $[38,39]$. In the case of yeast, an oxidoreductase mechanism is witnessed. Phytochelation synthase was secreted for reducing $\mathrm{Cd}^{+}$, whereas, Saccharomyces cerevisiae produced cadmium telluride quantum dots (CdTe QDs) extracellularly with help of protein ligands [40, 41]. The extracellular formation of silver and gold nanoparticles with help of secreted melanin produced by important yeast named Yarrowia lipolytica [42]. We thus conclude, various naturally produced enzymes and chemicals like nitrate reductase enzyme, quinine derivatives of naphthoquinones and anthraquinones, sulfate permease, sulfurylase, and sulfite reductase, cysteine desulfhydrase, phytochelation synthase, and mycobased melanin can be extracted from different organisms by autolysis method or using lysis-promoting agents so as to carry out synthesis of a varied range of bio-nanoparticles in an easier way.

Basically, the intracellular method involves trapping, bioreduction, and capping of the nuclei produced. Intracellular methods occupy certain ion transportation and electrostatic interaction between microbial cells and metal ions leading to the formation of nanoparticles, whereas the extracellular method comprises of secretion of enzymes, bioreduction, and capping of particles. A most common enzyme isolated so far is nitrate reductase which might be responsible for majority of AgNP production processes [43]. However, Singh [44] explained extracellular method is preferable for the synthesis of nanoparticles, i.e., because downstreaming and purification are easier when compared to the intracellular process which consecutively makes intracellular processes over all time-consuming and biosynthesis is unlikely to be costly. The extracellular method of synthesis can be wholly cheap and convenient against intracellular method which stands out to be the main purpose for biosynthesis (Fig. 2).

\section{Mycosynthesis of Nanoparticles}

Once the microbes are isolated, they can be screened for the production of nanoparticles and further purified for various applications. Among all microorganisms, bacteria and fungi were most often used until now. Researchers isolated Pseudomonas stutzeri from silver mines in 1999 which is known to have synthesized AgNPs for the first time in history, 


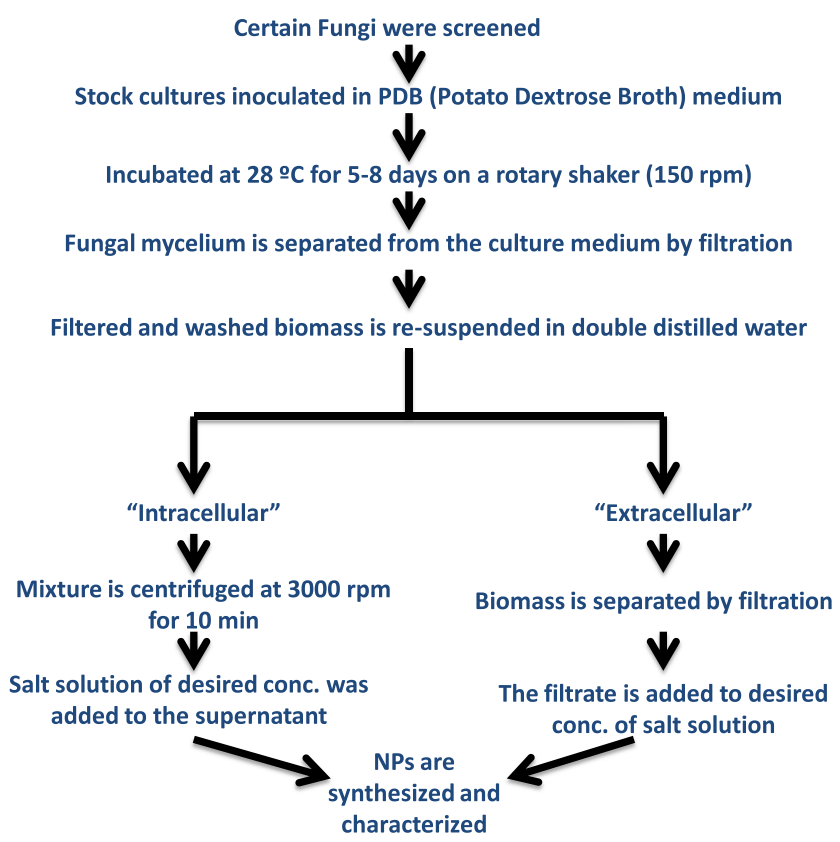

Fig. 2 Schematic representation of mycosynthesis of nanoparticles under extracellular and intracellular routes

and there have been many bacteria recognized to produce various metal nanoparticles [45]. Some of the bacterial species identified as efficient producers of nanoparticles are Magnetospirillum magneticum, Desulfovibrio desulfuricans NCIMB 8307 [46], Pseudomonas aeruginosa [47], Plectonema boryanum UTEX 485 [48-50], Rhodopseudomonas capsulate [51], Escherichia coli [52], Bacillus licheniformis, Lactobacillus sp. [53-55], and Bacillus cereus [56].

However, if we consider fungi, it showed equal potentials in synthesizing nanoparticles and thus are studied as elaborately as bacterial synthesis processes. Fungi were found to be more convenient since their biomasses can be easily developed and optimized according to our need, biomasses are simpler to handle, cheaper to grow, i.e., they are economically viable, their mycelial mats provide larger surface area for greater wall-binding capacity, produce comparatively higher quantity of enzymes responsible for diverse processes, help in comparatively larger scale of production of nanoparticles, have higher bio-accumulation capacity of nanoparticles due to their elevated tolerance level, and their synthesis can be either intra/extracellular but downstreaming is simpler in this case [5, 38, 57-60]. Fungal species include different Aspergillus spp., Fusarium spp., Verticillum spp., and Trichoderma spp., and endophytic fungi $[4,38,39,58$, 61-65] are known to produce silver, gold, as well as a variety of other metal nanoparticles. It was revealed that metals being toxic to the bacterial or fungal cells are reduced by certain reductase enzymes secreted by them, like $\alpha$-NADPHdependent reductases, nitrate-dependent reductases, or the metal ion bonds to the cell surface causing biosorption [66]. Both ways, microbes strive to remove the unnecessary particles from its surrounding. Fungi are more preferred organisms for such process when carried out in larger scales. A fungi secrete diverse group of enzymes, proteins, or peptides as reducing agents like naphthoquinones, anthraquinones, and nitrate reductase which break down metal ions into metal nanoparticles. These are specific to particular metals and act on them easily [39, 67, 68]. Also, some metal induces high oxidative stress in fungi and thus secretes proteins to inhibit any harmful actions of the metal. Due to the use of such enzyme and protein secretions, the size and shape of the nanoparticles can be simply controlled. These enzymatic processes are gaining a lot of interest in recent science even though the mechanism behind most of the processes is yet to be revealed. As mentioned earlier, mycosynthesis can be either extracellular or intracellular type. Extracellular synthesis involves secretion of responsible fungal enzymes into the media due to the presence of silver salts that creates a stressed environment for the organism. Furthermore, the metal is reduced into nanoparticles by these enzymes. Whereas, the negatively charged cell wall of fungi interrelates with positively charged metal ions due to enzymes present on cell wall membrane, in the case of the intracellular route [69].

Yeast, being members of kingdom fungi, are slightly different from the typical fungus since they are unicelled. As their cellular organization is similar to fungi, they are also considered for synthesizing silver and gold nanoparticles. As reported earlier, several yeast species successfully produced AuNPs, for example, a cold-adapted yeast, Y. lipolytica NCYC 78 [70], a tropical marine yeast $Y$. lipolytica NCIM 3589 [71], S. cerevisiae AP22, and CCFY-100 [72]. On the other hand, silver nanoparticles were synthesized by the silver-tolerant strain MKY3, dermatophytic species Trichophyton rubrum, Trichophyton mentagrophytes, Microsporum canis, Kluyveromyces marxianus, and Candida utili [73-76].

Ninganagouda et al. [77] demonstrated fungal synthesis of metal nanoparticles in three simple steps: Firstly, the organism of interest in mass cultured in respected media, most commonly potato dextrose broth (PDB). Secondly, well-grown mycelia mats are filtered from the chemically composed media, washed, and re-suspended in doubledistilled water. This step is carried out to avoid any interference of the chemicals present in the media of the process. Thirdly, the suspension obtained is formulated with different concentrations of metal salts and incubated. Nevertheless, intracellular production process necessitates the use of the mycelia mat instead of the filtrate since the responsible enzymes are established within the cell walls $[31,38,45]$. Particles formed are polydisperse due to the presence of different types of enzymes with assorted potency as secreted by the organisms employed. 


\subsection{Silver Nanoparticles}

Silver, as a metal, has always been significant in human health and diseases due to its natural powerful antimicrobial properties which help in wound healing, skin care, water purifier, etc. They easily interact with the microbial membranes and destroy cells which avoid or treat infectious diseases [78-80]. Certain microbes are becoming silver-resistant, and therefore, silver ions have failed in healing ailments in spite of having a number of beneficial qualities. Silver ions have very low toxic threshold, and they are not preferred as safe drugs in many therapies [81]. These shortcomings of silver metal led to nanosilver synthesis. Fungal synthesis of AgNPs has conquered large area in the field of nanobiotechnology where many scientists had and even now are exploring mycosynthesis of silver particles. Different fungal endophytes and pathogens were selected for synthesizing AgNPs by various researchers. Some of the important species such as, Fusarium graminearum, Fusarium solani, F. oxysporum, Fusarium culmorum, Fusarium scirpi, Fusarium tricinctum, A. flavus, Aspergillus sp., A. terreus, Penicillium sp., Fusarium moniliforme, A. concius, P. janthinellum, Phomosis sp. and many others proved to have fair ability to produce silver nanobiomolecules [19, 21, 82, 83]. Certain fungi isolated from various environmental sources were also evident for the synthesis of these colloidal particles. Scientists and different groups carried out formulations to illustrate fabrication of silver by fungi such as A. flavus [18], P. citrinum [84], Rhizoctonia sp. [22], F. oxysporum [85], and F. semitectum (KSU-4) [24]. Other fungi like Trichoderma viridae [86], Coriolus versicolor [8], Penicillium fellutanum [87], and Trichoderma asperellum [65] were also investigated for the synthesis of silver particles as well (Table 1).

The mechanism behind silver nanobiosynthesis process which fundamentally involves reduction instigated by electron transfer from the NADH by NADH-dependent reductase as electron carrier has partially been studied by several scientists [107]. They concluded $\alpha$-NADPH-dependent nitrate reductase, phytochelatin, or hydrogenase enzyme is chiefly responsible for AgNPs in several instances. Silver salt like silver nitrate is vastly used for bioreduction methods of AgNPs, and they are formed due to reducing agents mentioned above, and stabilizing agents are produced by fungi. According to assays performed, the cell wall containing carboxylate groups is negatively charged which interacts to the positively charged silver metal and fabricates nanosilver [108]. Fungal species, i.e., Phaenerochaete chrysosporium indicated secretion of reducing sugar which was also known to facilitate AgNP synthesis [109].

\subsection{Gold Nanoparticles}

Among metal nanoparticles, AuNPs have gained a lot of significance due to its inert nature which makes it undoubtedly non-toxic for human cells. Gold is scarcely investigated so far in comparison to silver for the synthesis of their relevant nanoparticles. Though gold as a metal is expensive, various research groups have extensively considered it for the synthesis of nanoparticles and applying them in biomedical applications $[102,110,111]$. Gold has proved to be the most biocompatible, stable, and eco-friendly nanomolecule. They have shown great functions in biosensors, cancer diagnostics, and therapy, in needle-free drug delivery and as antimicrobials [112]. According to previous reports, fungi have been extensively used in mycosynthesis in gold particle production. AuNPs in the size range of 10 to $200 \mathrm{~nm}$ were fabricated by diverse scientific groups by various fungal species like $A$. fumigates [25], Cylindrocladium floridanum [113], Sclerotium rolfsii [101], Epicoccum nigrum [102], F. solani [103], A. terreus IF0 [104], Hormoconis resinae [98], P. chrysosporium [90], Penicillium rugulosum [114], C. versicolor [8], Penicillium brevicompactum [115], A. niger [105], Candida albicans [116], Nocardia farcinica [117], Rhizopus oryzae [118], and Penicillium chrysogenum [119]. Fungi are known to be more efficient in producing the smaller size of AuNPs than bacteria. However, less than 50 fungal species are so far screened for the AuNP synthesis, and they are listed in Table 1.

Mechanism of AuNP synthesis is barely considered as part of nanobiotechnology research as yet, but it is explained in simple ways about how the enzymes and proteins work in synthesis process [90]. They clarified the routes where, enzymes like Laccase helps in the extracellular synthesis and protein side groups like amino groups, sulfhydryl groups, and carboxylic groups act in forming loci on the cell surface leading to crystal growth in case of the intracellular pathway. It is also stated that AuNP synthesis takes place again due to the same reason as that of AgNP synthesis, i.e., toxic stress in the microbial environment.

Explained earlier in this article, yeast is important in synthesizing silver and gold nanoparticles, but they are least studied in the field of nanotechnology. Different yeasts studied so far are cited in Table 2.

These nanoparticles being some of the best materials presently for application on biomedical devices, we richly pursue study on the mechanism of making its synthesis process effortless. We can also introduce different parameters in the synthesis process to get better yield, specific shapes, and sizes of the particles pertaining to different applications.

\section{Downstreaming and Purification of Nanoparticles}

Fungi are always preferred in today's nanobiotechnology research for synthesizing nanoparticles because of their easy and simple downstreaming process. In the case of bacterial production, the separation of enzymes secreted requires a lot of equipment like centrifugation, sonicator, and chemical agents such as methanol, whereas fungal filtrate can be effortlessly 
Table 1 List of fungal species synthesizing silver and gold nanoparticles

\begin{tabular}{|c|c|c|c|c|c|}
\hline Species & $\begin{array}{l}\mathrm{Ag} / \mathrm{Au} \\
\mathrm{NP}\end{array}$ & Size $(\mathrm{nm})$ & Morphology & $\begin{array}{l}\text { Intracellular/ } \\
\text { extracellular }\end{array}$ & Reference \\
\hline Alternaria sp. & $\mathrm{Ag}$ & $20-60$ & Polydisperse spherical & - & Gajbhiya et al. [88] \\
\hline F. oxysporum & $\mathrm{Ag}$ & $3-25$ & Spherical & Extracellular & Gaikwad et al. [82] \\
\hline Penicillium sp. & $\mathrm{Ag}$ & $3.71-65.92$ & Cubic nanoclusters & Intracellular & Chandrappa et al. [83] \\
\hline Phoma sp. 3.2883 & $\mathrm{Ag}$ & $71.06-74.46$ & Spherical & Intracellular & Chen et al. [89] \\
\hline Verticillium & $\mathrm{Ag}$ & $25 \pm 12$ & Spherical & Intracellular & Mukherjee et al. [38] \\
\hline $\begin{array}{l}\text { Trichoderma } \\
\text { asperellum }\end{array}$ & $\mathrm{Ag}$ & $13-18$ & Spherical & - & Mukherjee et al. [65] \\
\hline $\begin{array}{l}\text { Phaenerochaete } \\
\text { chrysosporium }\end{array}$ & $\mathrm{Ag}$ & $15-200$ & Spherical & Extracellular & Sanghi et al. [90] \\
\hline F. solani & $\mathrm{Ag}$ & 16.23 & Spherical & Extracellular & Ingle et al. [91] \\
\hline Aspergillus clavatus & $\mathrm{Ag}$ & $10-25$ & Polydisperse spherical or hexagonal & Extracellular & Verma et al. [92] \\
\hline A. fumigates & $\mathrm{Ag}$ & $5-25$ & Spherical & Extracellular & $\begin{array}{l}\text { Bhainsa and D'souza } \\
\text { [61] }\end{array}$ \\
\hline A. fumigates & $\mathrm{Ag}$ & 50 & Spherical & Extracellular & Navazi et al. [93] \\
\hline $\begin{array}{l}\text { Helminthosporum } \\
\quad \text { solani }\end{array}$ & $\mathrm{Au}$ & $15-20$ & $\begin{array}{l}\text { Mostly spheres, and number of rods, triangles, } \\
\text { pentagons, pyramids, and stars }\end{array}$ & Extracellular & Kumar et al. [94] \\
\hline A. terreus & $\mathrm{Ag}$ & $1-20$ & Spherical & Extracellular & Li et al. [95] \\
\hline F. acuminatum & $\mathrm{Ag}$ & $5-40$ & Spherical & Extracellular & Ingle et al. [96] \\
\hline F. semitectum & $\mathrm{Ag}$ & $10-60$ & Spherical & Extracellular & Basavaraja et al. [97] \\
\hline Hormoconis resinae & $\mathrm{Au}$ & $3-20$ & Spherical & Extracellular & Mishra et al. [98] \\
\hline Neurospora crassa & $\mathrm{Ag}$ & 60 & Spherical & Intracellular & $\begin{array}{l}\text { Castro-Longoria et al. } \\
\text { [59] }\end{array}$ \\
\hline $\begin{array}{l}\text { Penicillium } \\
\quad \text { brevicompactum }\end{array}$ & $\mathrm{Ag}$ & $23-105$ & Spherical & Extracellular & Shaligram et al. [99] \\
\hline $\begin{array}{l}\text { Penicillium } \\
\quad \text { fellutanum }\end{array}$ & $\mathrm{Ag}$ & $5-25$ & & Extracellular & Kathiresan et al. [87] \\
\hline Coriolus versicolor & $\begin{array}{l}\text { Capped } \\
\text { Ag }\end{array}$ & - & Spherical & Extracellular & Sanghi and Verma [8] \\
\hline Fusarium oxysporum & $\mathrm{Ag}$ & $5-13$ & Spherical & Extracellular & Husseiny et al. [47] \\
\hline Trichoderma viridae & $\mathrm{Ag}$ & $5-40$ & Spherical/occasionally rod-shaped & Extracellular & Fayaz et al. [100] \\
\hline Penicillium citrinum & $\mathrm{Ag}$ & 109 & Spherical & Extracellular & Honary et al. [84] \\
\hline Rhizoctonia sp. & $\mathrm{Ag}$ & $25-50$ & Plate-like & Extracellular & Raudabaugh et al. [22] \\
\hline $\begin{array}{l}\text { Cylindrocladium } \\
\text { floridanum }\end{array}$ & $\mathrm{Au}$ & 19.05 & Spherical & - & $\begin{array}{l}\text { Badrinarayanan and } \\
\text { Sakthivel [25] }\end{array}$ \\
\hline Sclerotium rolfsii & $\mathrm{Au}$ & 25 & $\begin{array}{l}\text { Triangles, hexagonals, decahedrals, and rods, and } \\
\text { isotrophic sphericals }\end{array}$ & Extracellular & Kannan et al. [101] \\
\hline Epicoccum nigrum & $\mathrm{Au}$ & $5-50$ & Spherical/rod-shaped & Extracellular & Sheikloo et al. [102] \\
\hline Fusarium solani & $\mathrm{Au}$ & $20-50$ & Spherical & Extracellular & $\begin{array}{l}\text { Gopinath and } \\
\text { Arumugam [103] }\end{array}$ \\
\hline $\begin{array}{l}\text { Aspergillus terreus } \\
\text { IFo }\end{array}$ & $\mathrm{Au}$ & $10-19$ & Spherical/rod & Extracellular & Priyadarshini et al. [104] \\
\hline $\begin{array}{l}\text { Phanerochaete } \\
\text { chrysosporium }\end{array}$ & $\mathrm{Au}$ & $10-100$ & Spherical & Extracellular & Sanghi et al. [90] \\
\hline Aspergillus niger & $\mathrm{Au}$ & $10-30$ & Various shapes & Extracellular & Soni and Prakash [105] \\
\hline Coriolos versicolor & $\mathrm{Au}$ & $5-30$ & Spherical or elliptical & Extracellular & Sanghi and Verma [106] \\
\hline
\end{tabular}

segregated from the mycelia mats by simple filtration technique. This helps in saving time, lesser use of intricate instruments, and thus making it an overall manageable procedure $[10,57,125]$. The downstream process in fungal synthesis method involves the separation of biomass from the filtrate which eventually can be used in the formulation with metal salts. Once the particles are formed, the colloidal solution containing these particles is freeze-dried and purified for 
characterization. Freeze-drying is carried out by lyophilizers, and the powder obtained is purified by different approaches which involve washing multiple times with Millipore water, heating at high temperature (within a melting point of metal concerned), and treating with agents (hydrogen peroxide, phosphoric acid) to remove organic materials.

The metal nanoparticles synthesized by fungal route have no particular method of purifying them so far, yet some researchers have carried out different techniques for this purpose. They have demonstrated varied ways of purifying nanoparticles to get rid of the impurities that might be present from the media used or the biomass involved or due to the organic molecules that cause aggregation in them. Silver nanoparticle formulations were spun at $10,000 \mathrm{rpm}$ for $10 \mathrm{~min}$ twice to purify and washed multiple times to remove impurities by centrifuging at $14,000 \mathrm{rpm}$ for $30 \mathrm{~min}$ by a group of researchers, whereas, another group passed the formulation through microfilters so as to obtain the same size range of particles and then separated them by discontinuous sucrose density gradient which is done using ultracentrifugation technique $[126,127]$. To purify monodispersed solution of stable gold particles, Al-Kazazz et al. [128] used dialysis membrane instead of employing an organic solvent like other researchers, since dialysis process does not require harmful chemicals. Again, removing unwanted impurities in form of supernatant from the concentrated pellets by centrifuging samples at high speed $(2000,5000,10,000,15,000 \mathrm{rpm}$ for $20 \mathrm{~min}$ ) is another common technique used [129], where large aggregates are removed first and gradually the pellets are rewashed to get finer and pure particles. These methods consequently help collect pure nanoparticles which can be undoubtedly further exploited in biomedical functions.

\section{Characterization of Bio-Nanoparticles}

Nanoparticle formation has to be confirmed by certain approaches so as to be able to employ them in their respective applications in future. Most preliminary mean to follow particle formation in a formulated solution is by visual observation of the color change. It can be further affirmed by detecting specific peaks given by nanoparticles in the visible regions from UV-vis spectrum of formulations using a spectrophotometer within the range 250 to $800 \mathrm{~nm}[130,131]$. X-Ray diffraction (XRD) analysis data is another important evidence of nanoparticle formation. Morphology, size, composition, and the distribution of nanoparticles can be studied by transmission electron microscopic (TEM) analysis, scanning electron microscope (SEM), energy dispersive spectroscopy (EDAX), dynamic light scattering (DLS), etc. The biomolecules influencing the synthesis and stabilization of nanoparticles are traced by FT-IR spectrum $[1,28,132]$.

Broadly, AgNP production in the test solution has shown a color change from pale yellow to reddish brown or dark

Table 2 List of yeast species synthesizing silver and gold nanoparticles

\begin{tabular}{|c|c|c|c|c|c|}
\hline Species & $\begin{array}{l}\mathrm{Ag} / \mathrm{Au} \\
\text { nanoparticle }\end{array}$ & Size $(\mathrm{nm})$ & Morphology & Intracellular/extracellular & Reference \\
\hline P. jadinii & $\mathrm{Au}$ & $\begin{array}{c}\text { Few to } \\
100\end{array}$ & $\begin{array}{l}\text { Triangles, hexagons, spheres, } \\
\text { and rods }\end{array}$ & Intracellular/extracellular & $\begin{array}{l}\text { Gericke and Pinches } \\
\quad[120]\end{array}$ \\
\hline MKY3 & $\mathrm{Ag}$ & $2-5 \mathrm{~nm}$ & Hexagonal & Extracellular & Kowshik et al. [74] \\
\hline Pichia capsulata & $\mathrm{Ag}$ & - & - & Extracellular & $\begin{array}{l}\text { Subramanian et al. } \\
\text { [121] }\end{array}$ \\
\hline Hansenula anomala & $\mathrm{Au}$ & $2-70$ & - & - & Kumar et al. [94] \\
\hline Saccharomyces cerevisiae & $\begin{array}{l}\mathrm{Au} \\
\mathrm{Ag}\end{array}$ & $\begin{array}{l}20-100 \\
5-20\end{array}$ & Spherical & $\begin{array}{l}\text { Extracellular } \\
\text { Extracellular }\end{array}$ & Lim et al. [122] \\
\hline Candida guilliermondii & $\mathrm{Au}$ & $\begin{array}{l}50-70 \\
10-20\end{array}$ & $\begin{array}{l}\text { Spherical } \\
\text { Spherical }\end{array}$ & $\begin{array}{l}\text { Extracellular } \\
\text { Extracellular }\end{array}$ & Mishra et al. [123] \\
\hline Yarrowia lipolytica & $\mathrm{Au}$ & $15-20$ & Nanoparticles and nanoplates & $\begin{array}{l}\text { Extracellular and } \\
\text { intracellular }\end{array}$ & $\begin{array}{l}\text { Pimprikar et al. } \\
\text { [124] }\end{array}$ \\
\hline $\begin{array}{l}\text { Saccharomyces cerevisiae, AP22 and } \\
\text { CCFY-100 }\end{array}$ & $\mathrm{Au}$ & $\begin{array}{l}15-20 \text { at } \\
1 \mathrm{~h}\end{array}$ & Spherical & Extracellular & Sen et al. [72] \\
\hline Candida utilis & $\mathrm{Ag}$ & $20-80$ & Spherical & Extracellular & Waghmare et al. [73] \\
\hline $\begin{array}{l}\text { Trichophyton rubrum, } \\
\text { Trichophyton mentagrophytes } \\
\text { Microsporum canis }\end{array}$ & $\begin{array}{l}\mathrm{Ag} \\
\mathrm{Ag}\end{array}$ & $\begin{array}{l}<50 \\
50-100 \\
50-70\end{array}$ & $\begin{array}{l}\text { Spherical } \\
\text { Spherical } \\
\text { Spherical }\end{array}$ & $\begin{array}{l}\text { Extracellular } \\
\text { Extracellular } \\
\text { Extracellular }\end{array}$ & Moazeni et al. [75] \\
\hline Kluyveromyces marxianus & $\mathrm{Ag}$ & $3-12$ & Spherical & Extracellular & Ashour [76] \\
\hline Candida utilis & $\mathrm{Ag}$ & $6-20$ & Spherical & Extracellular & \\
\hline
\end{tabular}


brown depending on the concentration of the metal salt used. As reported in several articles, brown solution confirmed the presence of AgNPs due to surface plasmon resonance (SPR) of the particles, and the color intensity increases with the increase in a number of nanoparticles in solution [19, 21, 77, 133]. Even when the biomass of the fungus is directly used for the purpose of synthesis, the color of the biomass turns brownish from colorless [18]. In contrast, control, that either consists of cell filtrate or metal salt solution alone, does not show any change in color.

Varied shades of red like ruby red, burgundy red, or a light or reddish purple color are commonly formed with different concentrations of chloroauric acid $\left(\mathrm{HAuCl}_{4}\right)$ due to the presence of AuNPs and their surface plasmon vibrations [25, 27, 134, 135]. Statements from scientists clearly depict the initial pale yellow color of the formulation changes with the change in gold salt concentrations, where, as the concentration increased the color was intensified starting from $0.5 \mathrm{mM}$ with pinkish red color to $1.5 \mathrm{mM}$ with a dark purple color. However, with a higher concentration of gold, the particles start agglomerating and interfere in further characterization studies [136].

Further characterization methods include two types of techniques: firstly, microscopy-based ones like SEM, TEM, and AFM which give an idea about the physical look of the particles and secondly, spectroscopy-based such as UV-vis, XRD, FT-IR, and DLS that help to determine their composition, structure, and properties.

\subsection{UV-Visible Spectroscopy}

This works on the principle of measuring the SPR frequency of the particles in the solution. Mukherjee et al. [65]described that the intensity of the peak obtained is related to a number of nanoparticles present, where, breadth and height of the peak are directly proportional to the concentration of particles. The number of particles in the test solution determines the height, while dispersity represents the broadness of UV spectrum peak. Also, polydispersity decides the number of peaks in UV spectrum analysis and the size of the particles shows certain shifts (blue and red shift) in the absorption spectra, i.e., peak is obtained at the position more towards higher wavelength if a particle size is big and vice versa [82, 137]. The wavelength region of surface plasmon absorption peak, the number of absorption peaks, and spectrum broadening are predominantly related to the shape of the nanoparticle; therefore, the UVvisible spectroscopy helps immensely in determining the size of particles as well.

As depicted in Figs. 3 and 4, the occurrence of the plasmon band in this instrument for AgNPs as well as AuNPs is measured at the resolution of $1 \mathrm{~nm}$ within the wavelength range of
250 to $800 \mathrm{~nm}[24,136]$. A colloidal solution of AgNP shows an intense peak at $400-450 \mathrm{~nm}$ according to the majority of studies carried out $[19,65,77,85,138]$. Gold particles illustrate an absorbance at $500-550 \mathrm{~nm}$ as reported in various works [95, 103, 132, 139].

\subsection{X-Ray Diffraction (XRD)}

X-Ray diffraction is the method to study simple or complicated crystalline structures, size, and diffraction patterns of any particles. The powdered sample of nanoparticles after freeze-drying is characterized by passing beams of X-ray which on collision with atoms gets scattered and interferes with each other. This process is recorded, and certain peaks are obtained in form of a graph which depicts the structure and size of the particular nanoparticle. This analysis by Shah et al. [31] confirms the crystalline structure according to the standard crystallographic database. The diffraction intensities are recorded in the range of 8 to $80^{\circ} 2 \theta$ angles.

Silver in powdered nanoform represents face center cubic (fcc) crystalline structure following the comparison of the peaks found in XRD graphs with the Joint Committee on Powder Diffraction Standards (JCPDS) File No. 040783 database. Mainly, four peaks are observed at planes (111), (200), (220), and (311) at $2 \theta$ angles calculated by Bragg's law [21, 133, 137, 140]. Gold nanocrystals also show similar fcc structure, and peaks are the same planes as silver $[105,134]$.

\subsection{Fourier Transform Infrared Spectroscopy (FT-IR)}

This particular study confirms any biomolecular compounds capping the nanoparticles and in turn makes them more stable in nature. This analytical technique measures infrared versus wavelength of light which helps to determine functional groups on mycosynthesized nanoparticles (Figs. 3 and 4). Powdered samples are recorded with a resolution $4 \mathrm{~cm}^{-1}$ in the range of $400-4000 \mathrm{~cm}^{-1}$ [24]. The commonly observed surface residues in the case of the fungal mediated AgNPs are amino acids and peptides which act as capping agents which prevent agglomeration. Previous articles confirm the presence of carboxylate ions $(-\mathrm{COO})$, alkenes $(\mathrm{C}=\mathrm{C})$, alkanes $(\mathrm{C}-\mathrm{C})$, amides $(\mathrm{C}-\mathrm{N})$, alcohols $(-\mathrm{OH})$, phenols, primary and secondary amines $(-\mathrm{NH})$, and carbonyl $(\mathrm{C}=\mathrm{O})$ groups which extend stability to the particle fabricated $[23,65]$. These groups originate depending on distinct fungal extract used for the synthesis process. Again, AuNPs are also found to be capped with similar groups like primary, secondary, or aromatic or aliphatic amines, hydroxyl, methylene, as well as carbonyl, amide I, and amide II [141]. 
a

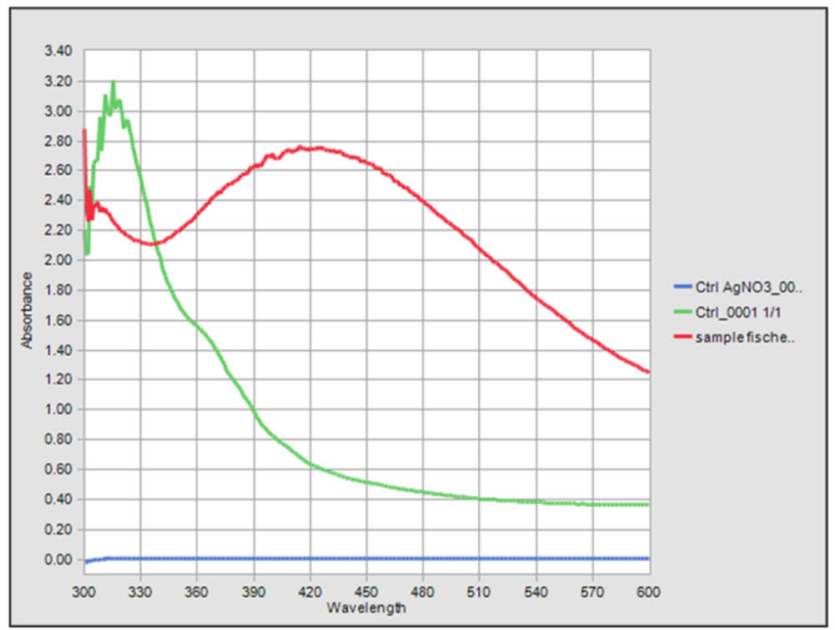

C

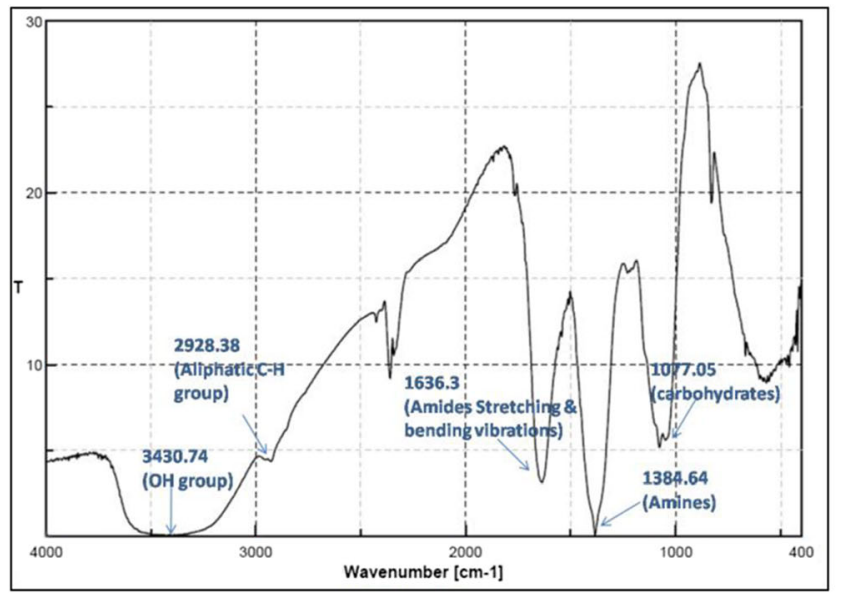

b

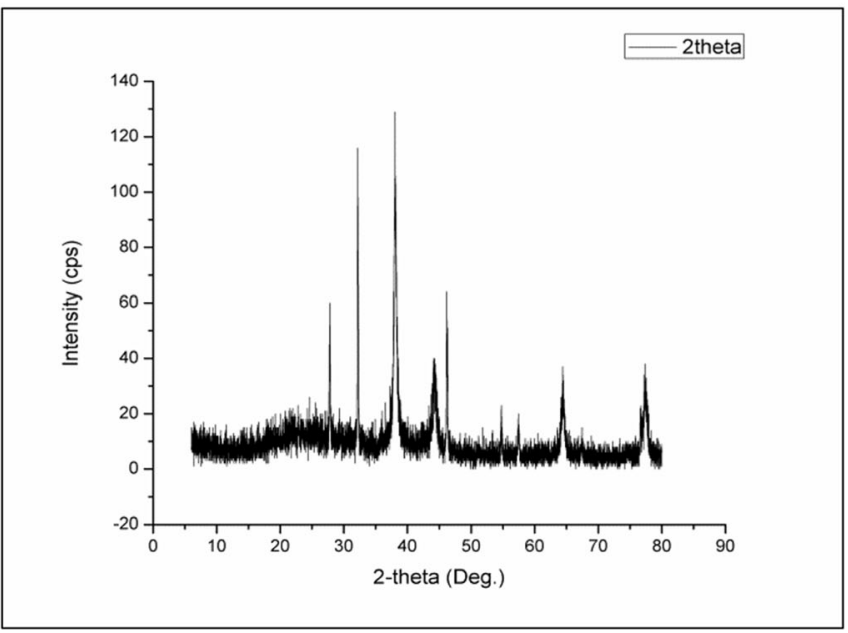

d

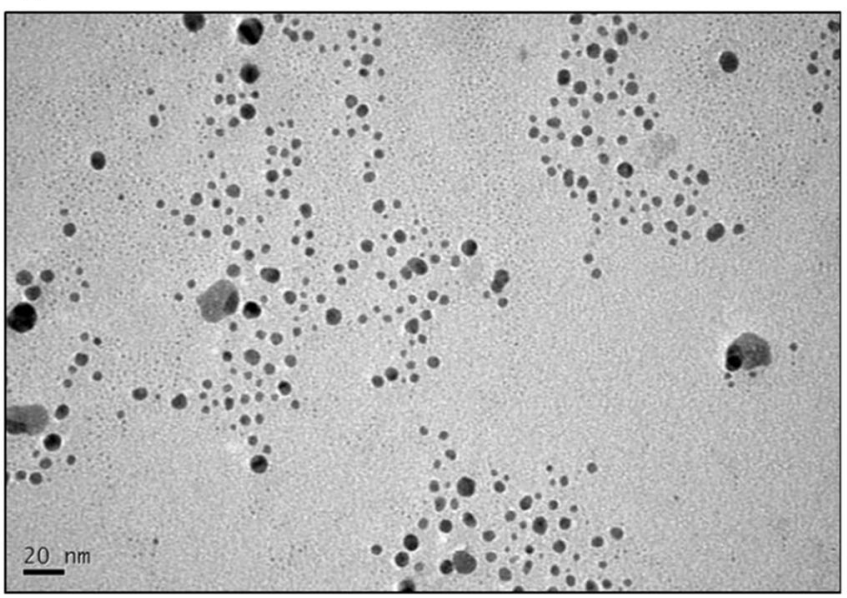

Fig. 3 Illustration of various characterization methods of silver nanoparticles (AgNPs)

\subsection{Scanning and Transmission Electron Microscopy (SEM and TEM)}

SEM or scanning electron microscope is an instrument which involves scanning of surface of the sample and backscattering of the ray is recorded. Since metal nanoparticles are highly electrically conductive, it is easy to scan them through SEM. Similarly, transmission electron microscope (TEM) helps in capturing images of nanoparticle samples based on the interaction of the electron beam in the high vacuum-conditioned chamber. SEM can be carried out by directly placing samples on the black surface that prevents unwanted scattering of the incident beam. In the case of TEM, the sample is prepared on carbon-coated copper grids using a single drop of the colloidal solution.

These microscopy techniques basically assist in finding out the size and shape of particles. So far, researchers detected various shapes like spherical, diamond, rod-like, and cubic with a wide range of sizes starting from as small as 1 to
$100 \mathrm{~nm}$ in diameter $[20,83,86,105,134,142,143]$ as demonstrated in the characterization figures. Thus, we can conclude the dominating shape and size of the particles in a formulated solution and standardize procedures to obtain the shape and size of our own interest.

\subsection{Energy Dispersive Spectroscopy (EDS)}

The method also known as energy dispersive X-ray (EDX) analysis is applied to find out the composition of nanoparticle sample [1]. The test powder is measured at an accelerating voltage of $10 \mathrm{kV}$, and optical absorption band peaks are formed at typical positions for specific elemental metal due to SPR. Metallic silver nanocrystallites show an absorption band at $\sim 2$ to $3 \mathrm{keV}$ along with $\mathrm{C}$ and $\mathrm{O}$ signatures in some instances [21, 77, 144], while gold showed a band at $2 \mathrm{keV}$ characteristic of AuNPs. There is a presence of carbon, oxygen, and nitrogen atoms due to the extract used in synthesis $[145,146]$. 


\section{a}

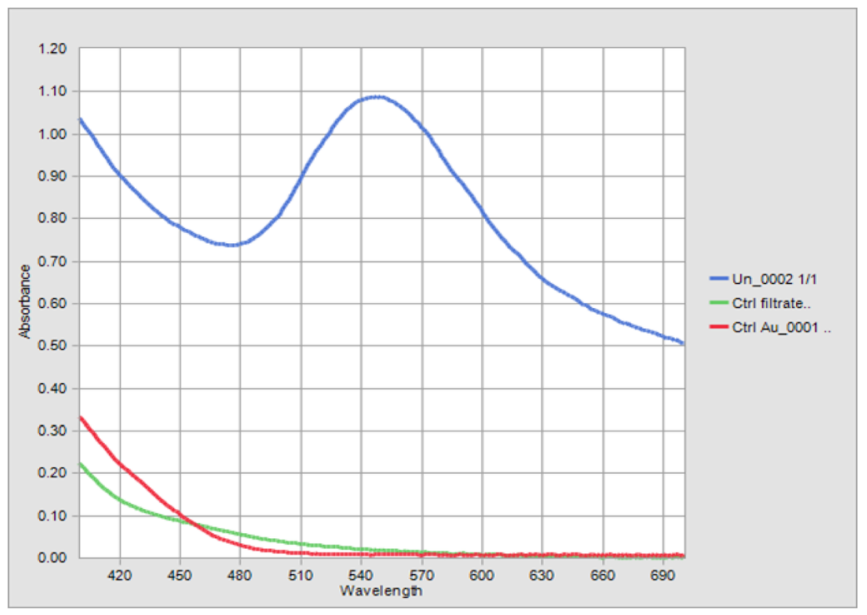

C

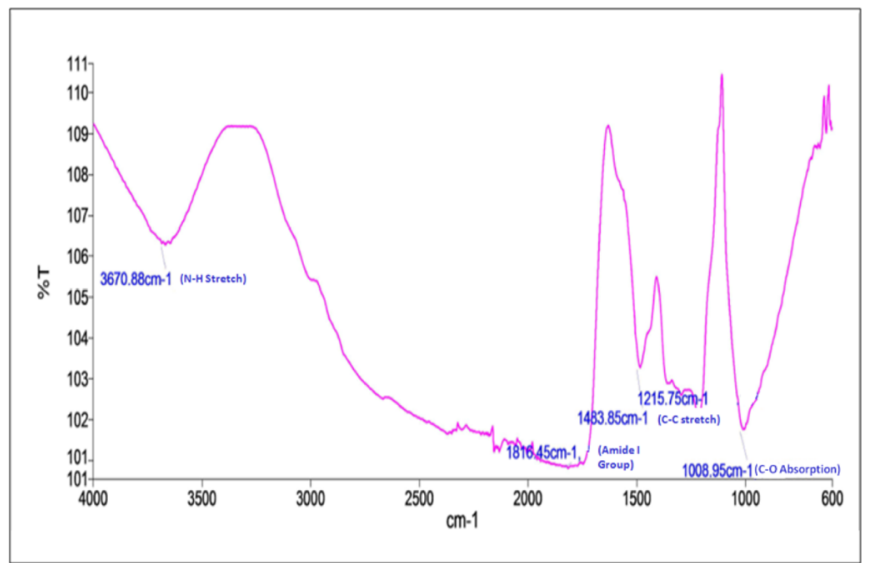

b

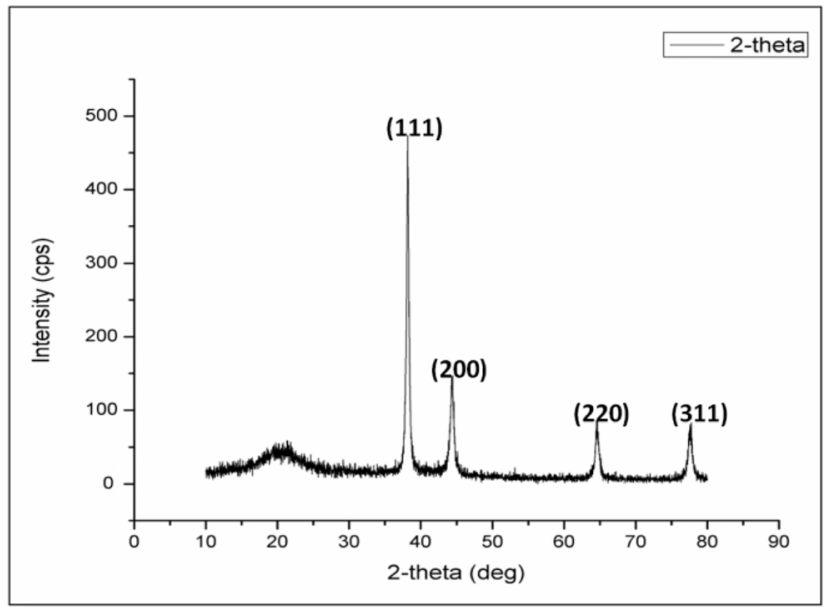

d

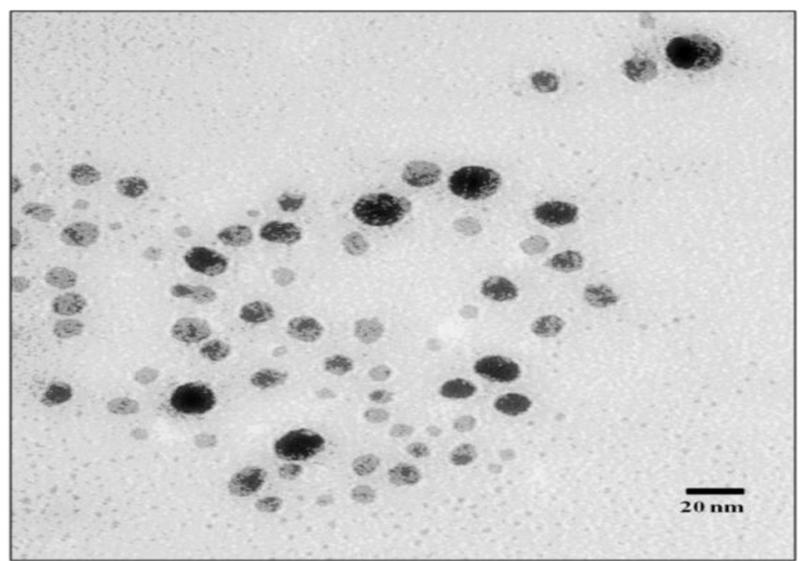

Fig. 4 Graphs depicting characterization methods of gold nanoparticles (AuNPs)

\subsection{Dynamic Light Scattering (DLS)}

The size distribution and surface charge of the particles can be checked by this technique. This works on the principle of interaction of particles with light. The amount of light scattered in the colloidal solution due to the presence of particles can be related to their diameter. According to Akbari et al. [147], this technique can be used to measure particles in the range of $1-500 \mathrm{~nm}$ but, it is difficult to record their sizes when agglomerated. The pure filtered nanoparticle dried samples are dissolved in a solvent, and the mean size, as well as charge on them, is analyzed by means of the instrument at $25{ }^{\circ} \mathrm{C}$ with a scattering angle of $90^{\circ}$ [141]. Moreover, the time-dependent study of the nanoparticle formation can also be carried out applying DLS. Zeta potential is measured by the peak number and peak area which fundamentally involve the charge on the particles. Negative charge provides evidence of particle size being smaller than $100 \mathrm{~nm}$ and vice versa. The smaller the particles, the more stable they are $[23$,
132]. Sometimes, the size determined by DLS, XRD, and TEM differs depending on the capping agent present on the nanoparticles, where the size calculated by DLS is bigger compared to other measurements [65].

\section{Drawbacks and Future Prospects}

Mycosynthesis of nanoparticles being useful in several ways has gained attention in present nanotechnology research, and it is very much employed in different synthesizing metal nanoparticles. However, every process has its own shortcomings from a scientific point of view. Similarly, problems behind fungal synthesis methods are studied here and specified. To start with, pathogenic microorganisms especially extracts from fungal species used might contain disease-causing spores which if spread may lead to safety risk sometimes and acts as a hazard to the ecosystem [3]. Secondly, mycosynthesis of silver and gold nanoparticles is yet to be studied elaborately; therefore, researchers do not possess the 
ability to control nanoparticle formation, their shape, size, and size distribution faultlessly. Also, very less knowledge has been acquired on the stability and aggregation of mycosynthesized particles. Next, biggest disadvantage of fungal synthesis is polydispersity in the formulation due to unknown reasons. Alongside, the particle size is also found to be bigger in some cases which might interfere in future application aspects [147, 148]. Lastly, since fungus is a eukaryotic organism, it is difficult to deal with its genes in order to identify responsible enzymes in this route. In short, the mechanism of reaction of formation and secretion of the enzymes in this process is hardly understood which causes a major drawback in further recognition of mycosynthesis $[69,148]$. Apart from the above-mentioned problems, particles formed by fungal route are essential to be purified; however, downstreaming is difficult as it requires equipment like centrifugation, hot air oven, and lyophilizer, and it comparatively is timeconsuming.

As we have discerned, the fact that mycosynthetic process of producing AgNP and AuNP is much safer, and economically, it should be considered to be studied in further details. Their immense use in pharmaceutics and other important aspects of medical sciences like delivery of the drug, cancer therapy, gene treatment, DNA analysis, antibacterial factors, biosensors, increasing response rates, separation science, and MRI is leading us to broadly deal with their morphological characteristic. Also, different methods for purifying mycosynthesised particles have also been explored recently which can be undoubtedly applied in the biomedical field. Mycosynthesis process being inexpensive and eco-friendly is analytically exploited by scientists, and numbers of fungi are being screened. Consequently, discoveries in this field are entitled to develop in future as silver and gold nanomaterials are important as antibiotics, antibiofilm agents, catalysts, anticancerous agents, antiproliferative agents, etc.

Acknowledgments The authors wish to acknowledge the financial support provided by the UGC, India, under the program of the University of Potential Excellence (UPE).

\section{References}

1. Siddiqi, K. S., \& Husen, A. (2016). Fabrication of metal nanoparticles from fungi and metal salts: scope and application. Nanoscale Research Letters, 11, 98.

2. Ramya, M., \& Subapriya, M. S. (2012). Green synthesis of silver nanoparticles. International Journal of Pharma Medical and Biological Sciences, 1, 2278.

3. Pantidos, N., \& Horsfall, L. E. (2014). Biological synthesis of metallic nanoparticles by bacteria, fungi and plants. Journal of Nanomedicine and Nanotechnol, 5, 1.

4. Mukherjee, P., Ahmad, A., Mandal, D., Senapati, S., \& Sainkar, S. R. (2001a). Bioreduction of $\mathrm{AuCl}(4)(-)$ ions by the fungus,
Verticillium sp. and surface trapping of the gold nanoparticles formed. Angewandte Chemie, International Edition, 40, 3585.

5. Ahmad, A., Mukherjee, P., Senapati, S., Mandal, D., Khan, M. I., Kumar, R., \& Sastry, M. (2003). Extracellular biosynthesis of silver nanoparticles using the fungus Fusarium oxysporum. Colloids and Surfaces, B: Biointerfaces, 28, 313.

6. Balaji, D. S., Basavaraja, S., Deshpande, R., Mahesh, D. B., Prabhakar, B. K., \& Venkataraman, A. (2009). Extracellular biosynthesis of functionalized silver nanoparticles by strains of Cladosporium cladosporioides fungus. Colloids and Surfaces, B: Biointerfaces, 68, 88.

7. Sadowski, Z., Maliszewska, I. H., Grochowalska, B., Polowczyk, I., \& Koźlecki, T. (2008). Synthesis of silver nanoparticles using microorganisms. Materials Science - Poland, 26, 419.

8. Sanghi, R., \& Verma, P. (2009). Biomimetic synthesis and characterisation of protein capped silver nanoparticles. Bioresource Technology, 100, 501.

9. Saravanan, M., \& Nanda, A. (2010). Extracellular synthesis of silver bionanoparticles from Aspergillus clavatus and its antimicrobial activity against MRSA and MRSE. Colloids and Surfaces, B: Biointerfaces, 77, 214.

10. Gade, A. K., Bonde, P., Ingle, A. P., Marcato, P. D., Durán, N., \& Rai, M. K. (2008). Exploitation of Aspergillus niger for synthesis of silver nanoparticles. Journal of Biobased Materials and Bioenergy, 2, 243.

11. Namasivayam, S. K. R., \& Avimanyu. (2011). Silver nanoparticle synthesis from Lecanicillium lecanii and evalutionary treatment on cotton fabrics by measuring their improved antibacterial activity with antibiotics against Staphylococcus aureus (ATCC 29213) and E. coli (ATCC 25922) strains. International Journal of Pharmacy and Pharmaceutical Sciences, 3, 190.

12. Du, L., Xu, Q., Huang, M., Xian, L., \& Feng, J. X. (2015). Synthesis of small silver nanoparticles under light radiation by fungus Penicillium oxalicum and its application for the catalytic reduction of methylene blue. Materials Chemistry and Physics, $160,40$.

13. Banerjee, K., \& Rai, V. R. (2016). Study on green synthesis of gold nanoparticles and their potential applications as catalysts. Journal of Cluster Science, 27, 1307.

14. Banerjee, K., \& Rai, V. R. (2015). Biofilm inhibitory activity of mycosynthesized silver nanoparticles against plaque forming bacteria Pseudomonas aeruginosa. Journal of Nanopharmaceutics and Drug Delivery, 3, 63.

15. Banerjee, K., \& Rai, V. R. (2015). Preliminary screening of mycochemicals in Aspergillus fischeri for synthesizing silver nanoparticles and their antioxidant activity. Materials Focus, 4, 252.

16. Goswami, A. M., Sarkar, T. S., \& Ghosh, S. (2013). An ecofriendly synthesis of silver nano-bioconjugates by Penicillium citrinum (MTCC9999) and its antimicrobial effect. AMB Express, 3, 16.

17. Shugaba, A., Buba, F., Kolo, B. G., Nok, A. J., Ameh, D. A., \& Lori, J. A. (2012). Uptake and reduction of hexavalent chromium by Aspergillus niger and Aspergillus parasiticus. Journal of Petroleum \& Environmental Biotechnology, 3, 1.

18. Moharrer, S., Mohammadi, B., Gharamohammadi, R. A., \& Yargoli, M. (2012). Biological synthesis of silver nanoparticles by Aspergillus flavus, isolated from soil of Ahar copper mine. Indian Journal of Science and Technology, 5, 2443.

19. Bharathidasan, R., \& Panneerselvam, A. (2012). Biosynthesis and characterization of silver nanoparticles using endophytic fungi Aspergillus concius, Penicillium janthinellum and Phomosis sp. International Journal of Pharmaceutical Sciences and Research, 3,3163 .

20. Devika, R., Elumalai, S., Arumugam, P., \& Kasinathan, K. (2012). Biosynthesis of silver nanoparticles using the fungus Pleurotus 
ostreatus and their antibacterial activity. Journal of Nanoscience, Nanoengineering \& Applications, $1,1$.

21. Rathna, G. S., Elavarasi, A., Peninal, S., Subramanian, J., Mano, G., \& Kalaiselvam, M. (2013). Extracellular biosynthesis of silver nanoparticles by endophytic fungus Aspergillus terreus and its anti-dermatophytic activity. International Journal of Pharmaceutical and Biological Archive, 4, 481.

22. Raudabaugh, D. B., Tzolov, M. B., Calabrese, J. P., \& Overton, B. E. (2013). Synthesis of silver nanoparticles by a Bryophilous rhizoctonia species. Nanomaterials and Nanotechnology, 3, 1.

23. Birla, S. S., Gaikwad, S. C., Gade, A. K., \& Rai, M. K. (2013). Rapid synthesis of silver nanoparticles from Fusarium oxysporum by optimizing physicocultural conditions. Scientific World Journal, 2013, 1.

24. Mahmoud, M. A., Al-Sohaibani, S. A., Alothman, M. R., ARM, A. E.-A., \& Eifan, S. A. (2013). Synthesis of extracellular silver nanoparticles using Fusarium semitectum (KSU-4) isolated from Saudi Arabia. Digest Journal of Nanomaterials and Biostructures, 8,589 .

25. Bathrinarayanan, P. V., Thangavelu, D., Muthukumarasamy, V. K., Munusamy, C., \& Gurunathan, B. (2013). Biological synthesis and characterization of intracellular gold nanoparticles using biomass of Aspergillus fumigates. Bulletin of Materials Science, 36, 1201.

26. Correa-Llantén, D. N., Muñoz-Ibacache, S. A., Castro, M. E., Muñoz, P. A., \& Blamey, J. M. (2013). Gold nanoparticles synthesized by Geobacillus sp. strain ID17 a thermophilic bacterium isolated from Deception Island, Antarctica. Microbial Cell Factories, 12, 75.

27. Moghaddam, A. M., Namvar, F., Moniri, M., Tahir, P. M., Azizi, S., \& Mohamad, R. (2015). Nanoparticles biosynthesized by fungi and yeast: a review of their preparation, properties, and medical applications. Molecules, 20, 16540.

28. Siemieniec, J. (2013). Synthesis of silver and gold nanoparticles using methods of green chemistry. Chemistry, 67, 842.

29. Kulkarni, N., \& Muddapur, U. (2014). Biosynthesis of metal nanoparticles: a review. Journal of Nanotechnology, 2014, 1.

30. Ganesan, V., Deepa, B., Nima, P., \& Astalakshmi, A. (2014). Bioinspired synthesis of silver nanoparticles using leaves of Millingtonia hortensis L.F. International Journal of Advanced Biotechnology and Research, 5, 93.

31. Shah, M., Fawcett, D., Sharma, S., Tripathy, S. K., \& Poinern, G. E. (2015). Green synthesis of metallic nanoparticles via biological entities. Journal of Materials, 8, 7278.

32. Sintubin, L., De Windt, W., Dick, J., Mast, J., Van der Ha, D., Verstarete, W., \& Boon, N. (2009). Lactic acid bacteria as reducing and capping agent for the fast and efficient production of silver nanoparticles. Applied Microbiology and Biotechnology, 84, 741.

33. Iravani, S. (2014). Bacteria in nanoparticle synthesis: current status and future prospects. International Scholarly Research Notices, 2014, 1.

34. Narayanan, K. B., \& Sakthivel, N. (2010). Biological synthesis of metal nanoparticles by microbes. Advances in Colloid and Interface Science, 156, 1.

35. Nangia, Y., Wangoo, N., Goyal, N., Shekhawat, G., \& Suri, C. R. (2009). A novel bacterial isolate Stenotrophomonas maltophilia as living factory for synthesis of gold nanoparticles. Microbial Cell Factories, 8, 39.

36. Bai, H. J., Zhang, Z. M., \& Gong, J. (2006). Biological synthesis of semiconductor zinc sulfide nanoparticles by immobilized Rhodobacter sphaeroides. Biotechnology Letters, 28, 1135.

37. Bai, H. J., Zhang, Z. M., Guo, Y., \& Yang, G. E. (2009). Biosynthesis of cadmium sulfide nanoparticles by photosynthetic bacteria Rhodopseudomonas palustris. Colloids and Surfaces B: Biointerfaces, 70, 142.
38. Mukherjee, P., Ahmad, A., Mandal, D., Senapati, S., \& Sainkar, S. (2001b). Fungus-mediated synthesis of silver nanoparticles and their immobilization in the mycelial matrix - a novel biological approach to nanoparticles synthesis. Nano Letters, 1, 515.

39. Durán, N., Marcato, P. D., Alves, O. L., De Souza, G. I., \& Esposito, E. J. (2005). Mechanistic aspects of biosynthesis of silver nanoparticles by several Fusarium oxysporum strains. Nanobiotechnology, 3, 1.

40. Krumov, N., Oder, S., Perner-Nochta, I., Angelov, A., \& Posten, C. (2007). Accumulation of CdS nanoparticles by yeasts in a fedbatch bioprocess. Journal of Biotechnology, 132, 481.

41. Bao, H., Hao, N., Yang, Y., \& Zhao, D. (2010). Biosynthesis of biocompatible cadmium telluride quantum dots using yeast cells. Nano Research, 3, 481.

42. Apte, M., Girme, G., Bankar, A., Kumar, A. R., \& Zinjarde, S. (2013). 3, 4-dihydroxy-L-phenylalanine-derived melanin from Yarrowia lipolytica mediates the synthesis of silver and gold nanostructures. Journal of Nanbiotechnology, 11, 2.

43. Hulkoti, N. I., \& Taranath, T. C. (2014). Biosynthesis of nanoparticles using microbes-a review. Colloids and Surfaces B. Biointerfaces, 121, 474.

44. Singh, O. V. (2015). Bio-nanoparticles-biosynthesis and sustainable biotechnological implications. New Jersey: Wiley Blackwell.

45. Klaus, T., Joerger, R., Olsson, E., \& Granqvist, C. G. (1999). Silver based crystalline nanoparticles, microbially fabricated. Proceedings of the National Academy of Sciences, 96(24), 13611.

46. Yong, P., Rowson, N. A., Farr, J. P. G., Harris, I. R., \& Macaskie, L. E. (2002). Bioreduction and biocrystallization of palladium by Desulfovibrio desulfuricans NCIMB 8307. Biotechnology and Bioengineering, 80, 369.

47. Husseiny, S. M., Salah, T. A., \& Anter, H. A. (2015). Biosynthesis of size controlled silver nanoparticles by Fusarium oxysporum, their antibacterial and antitumor activities. Beni-Suef University Journal of Basic and Applied Sciences, 4, 225.

48. Lengke, M., \& Southam, G. (2006). Bioaccumulation of gold by sulfate-reducing bacteria cultured in the presence of gold(I)-thiosulfate complex. Geochimica et Cosmochimica Acta, 70, 3646.

49. Lengke, M., Fleet, M. F., \& Southam, G. (2006a). Morphology of gold nanoparticles synthesized by filamentous cyanobacteria from gold(I)-thiosulfate and gold(III)-chloride complexes. Langmuir, 22, 2780 .

50. Lengke, M., Ravel, B., Fleet, M. E., Wanger, G., Gordon, G. A., \& Southam, G. (2006b). Mechanisms of gold bioaccumulation by filamentous cyanobacteria from gold(III)-chloride complex. Environmental Science \& Technology, 40, 6304.

51. He, S., Guo, Z., Zhang, Y., Zhang, S., \& Wang, J. (2007). Biosynthesis of gold nanoparticles using the bacteria Rhodopseudomonas capsulate. Materials Letters, 61, 3984.

52. Lloyd, J. R., Yong, P., \& Macaskie, L. E. (1998). Enzymatic recovery of elemental palladium by using sulfate-reducing bacteria. Applied and Environmental Microbiology, 64, 4607.

53. Nair, B., \& Pradeep, T. (2002). Coalescence of nanoclusters and formation of submicron crystallites assisted by Lactobacillus strains. Crystal Growth and Design, 2, 293.

54. Prasad, K., Jha, A. K., \& Kulkarni, A. R. (2007). Lactobacillus assisted synthesis of titanium nanoparticles. Nanoscale Research Letters, 2, 248.

55. Korbekandi, H., Iravani, S., \& Abbasi, S. (2012). Optimization of biological synthesis of silver nanoparticles using Lactobacillus casei subsp Casei. Journal of Chemical Technology and Biotechnology, 87, 932.

56. Sunkar, S., \& Nachiyar, C. V. (2012). Biogenesis of antibacterial silver nanoparticles using the endophytic bacterium Bacillus cereus isolated from Garcinia xanthochymu. Asian Pacific Journal of Tropical Biomedicine, 12, 953. 
57. Sastry, M., Ahmad, A., Khan, M. I., \& Kumar, R. (2003). Biosynthesis of metal nanoparticles using fungi and actinomycetes. Current Science, 85, 162.

58. Castro-Longoria, E., Vilchis-Nestor, A. R., \& Avalos-Borja, M. (2011). Biosynthesis of silver, gold and bimetallic nanoparticles using the filamentous fungus Neurospora crassa. Colloids and Surfaces B: Biointerfaces, 83, 42.

59. Castro-Longoria, E., Moreno-Velásquez, S. D., Vilchis-Nestor, A. R., Arenas-Berumen, E., \& Avalos-Borja, M. (2012). Production of platinum nanoparticles and nano aggregates using Neurospora crassa. Journal of Microbiology and Biotechnology, 22, 1000.

60. Volesky, B., \& Holan, Z. R. (1999). Biosorption of heavy metals. Biotechnology Progress, 11, 235.

61. Bhainsa, K. C., \& D'Souza, S. F. (2006). Extracellular biosynthesis of silver nanoparticles using the fungus Aspergillus fumigates. Colloids and Surfaces B: Biointerfaces, 47, 160.

62. Ahmad, A., Mukherjee, P., Mandal, D., Senapati, S., \& Khan, M. I. (2002). Enzyme mediated extracellular synthesis of CdS nanoparticles by the fungus, Fusarium oxysporum. Journal of the American Chemical Society, 124, 12108.

63. Vahabi, K., Mansoori, G. A., \& Karimi, S. (2011). Biosynthesis of silver nanoparticles by fungus Trichoderma reesei (a route for large-scale production of AgNPs). Insciences Journal, 1, 65.

64. Bharde, A., Rautaray, D., Bansal, V., Ahmad, A., \& Sarkar, I. (2006). Extracellular biosynthesis of magnetite using fungi. Small, 2, 135.

65. Mukherjee, P., Roy, M., Mandal, B. P., Dey, G. K., Mukherjee, P. K., Ghatak, J., Tyagi, A. K., \& Kale, S. P. (2008). Green synthesis of highly stabilized nanocrystalline silver particles by a nonpathogenic and agriculturally important fungus $T$. asperellum. Nanotechnology, 19, 1.

66. Alghuthaymia, M. A., Almoammarb, H., Raic, M., Said-Galievd, E., \& Abd-Elsalam, K. A. (2015). Myconanoparticles: synthesis and their role in phytopathogens management. Biotechnology and Biotechnological Equipment, 29, 221.

67. Usha, R., Prabu, E., Palaniswamy, M., Venil, C. K., \& Rajendran, R. (2010). Synthesis of metal oxide nano particles by Streptomyces sp for development of antimicrobial textiles. Global Journal of Biotechnology \& Biochemistry, 5, 153.

68. Kumar, S. A., Abyaneh, M. K., Gosavi, S. W., Kulkarni, S. K., Pasricha, R., Ahmad, A., \& Khan, M. I. (2007). Nitrate reductasemediated synthesis of silver nanoparticles from $\mathrm{AgNO}_{3}$. Biotechnology Letters, 29, 439.

69. Thakkar, K. N., Mhatre, S. S., \& Parikh, R. Y. (2010). Biological synthesis of metallic nanoparticles. Nanomedicine: Nanotechnology, Biology and Medicine, 6, 257.

70. Nair, V., Sambre, D., Joshi, S., Bankar, A., Kumar, A. R., \& Zinjarde, S. (2013). Yeast-derived melanin mediated synthesis of gold nanoparticles. Journal of Bionanoscience, 7, 159.

71. Agnihotria, M., Joshia, S., Ravi, A. K., Zinjardea, S., \& Kulkarni, S. (2009). Biosynthesis of gold nanoparticles by the tropical marine yeast Yarrowia lipolytica NCIM 3589. Materials Letters, 63, 1231.

72. Sen, K., Sinha, P., \& Lahiri, S. (2011). Time dependent formation of gold nanoparticles in yeast cells: a comparative study. Biochemical Engineering Journal, 55, 1.

73. Waghmare, S. R., Mulla, M. N., Marathe, S. R., \& Sonawane, K. D. (2015). Ecofriendly production of silver nanoparticles using Candida utilis and its mechanistic action against pathogenic microorganisms. 3 Biotech, 5, 33.

74. Kowshik, M., Ashtaputre, S., Kharrazi, S., Vogel, W., Urban, J., Kulkarni, S. K., \& Paknikar, K. M. (2003). Extracellular synthesis of silver nanoparticles by a silver-tolerant yeast strain MKY3. Nanotechnology, 14, 95.

75. Moazeni, M., Rashidi, N., Shahverdi, A. R., Noorbakhsh, F., \& Rezaie, S. (2012). Extracellular production of silver nanoparticles by using three common species of dermatophytes: Trichophyton rubrum, Trichophyton mentagrophytes and Microsporum canis. Iranian Biomedical Journal, 16, 52.

76. Ashour, S. M. (2014). Silver nanoparticles as antimicrobial agent from Kluyveromyces marxianus and Candida utilis. International Journal of Current Microbiology and Applied Sciences, 3, 384.

77. Ninganagouda, S., Rathod, V., \& Singh, D. (2014). Characterization and biosynthesis of silver nanoparticles using a fungus Aspergillus niger. International Letters of Natural Sciences, 15, 49.

78. Davies, R. L., \& Etris, S. F. (1997). The development and functions of silver in water purification and disease control. Catalysis Today, 36, 107.

79. Silvestry-Rodriguez, N., Sicairos-Ruelas, E. E., Gerba, C. P., \& Bright, K. R. (2007). Silver as a disinfectant. Reviews of Environmental Contamination and Toxicology, 191, 23.

80. Brady, M. J., Lisay, C. M., Yurkovetskiy, A. V., \& Sawan, S. P. (2003). Persistent silver disinfectant for the environmental control of pathogenic bacteria. American Journal of Infection Control, 31, 208.

81. Lansdown, A. B. (2006). Silver in health care: antimicrobial effects and safety in use. Current Problems in Dermatology, 33, 17.

82. Gaikwad, S. C., Birla, S. S., Ingle, A. P., Gade, A. K., Marcato, P. D., Rai, M., \& Duran, N. (2013). Screening of different Fusarium species to select potential species for the synthesis of silver nanoparticles. Journal of the Brazilian Chemical Society, 24, 1974.

83. Chandrappa, C. P., Govindappa, M., Chandrasekar, N., Sarkar, S., Ooha, S., \& Channabasava, R. (2016). Endophytic synthesis of silver chloride nanoparticles from Penicillium sp. of Calophyllum apetalum. Advances in Natural Sciences: Nanoscience and Nanotechnology, 7, 025016.

84. Honary, S., Barabadi, H., Gharaei-Fathabad, E., \& Naghibi, F. (2013). Green synthesis of silver nanoparticles induced by the fungus Penicillium citrinum. Tropical Journal of Pharmaceutical Research, 12, 7.

85. Ishida, K., Cipriano, T. F., Rocha, G. M., Weissmüller, G., Gomes, F., Miranda, K., \& Rozental, S. (2013). Silver nanoparticle production by the fungus Fusarium oxysporum: nanoparticle characterization and analysis of antifungal activity against pathogenic yeasts. Memórias do Instituto Oswaldo Cruz, 109, 220.

86. Fayaz, A. M., Balaji, K., Girilal, M., Kalaichelvan, P. T., \& Venkatesan, R. (2009). Mycobased synthesis of silver nanoparticles and their incorporation into sodium alginate films for vegetable and fruit preservation. Journal of Agricultural and Food Chemistry, 57, 6246.

87. Kathiresan, K., Manivannan, S., Nabeel, M., \& Dhivya, B. (2009). Studies on silver nanoparticles synthesized by a marine fungus, Penicillium fellutanum isolated from coastal mangrove sediment. Colloids and Surfaces B: Biointerfaces, 71, 133.

88. Gajbhiye, M., Kesharwan, I. J., Ingle, A., Gade, A., \& Rai, M. (2009). Fungus mediated synthesis of silver nanoparticles and their activity against pathogenic fungi in combination with fluconazole. Nanomedicine, 5, 382 .

89. Chen, J. C., Lin, Z. H., \& Ma, X. X. (2003). Evidence of the production of silver nanoparticles via pretreatment of Phoma sp.3.2883 with silver nitrate. Letters in Applied Microbiology, 37, 105.

90. Sanghi, R., Verma, P., \& Puri, S. (2011). Enzymatic formation of gold nanoparticles using Phanerochaete chrysosporium. Advances in Chemical Engineering and Science, 1, 154.

91. Ingle, A., Rai, M., Gade, A., \& Bawaskar, M. (2009). Fusarium solani: a novel biological agent for the extracellular synthesis of silver nanoparticles. Journal of Nanoparticle Research, 11, 2079.

92. Verma, V. C., Kharwar, R. N., \& Gange, A. C. (2010). Biosynthesis of antimicrobial silver nanoparticles by the endophytic fungus Aspergillus clavatus. Nanomedicine, 5, 33. 
93. Navazi, Z. R., Pazouki, M., \& Halek, F. S. (2010). Investigation of culture conditions for biosynthesis of silver nanoparticles using Aspergillus fumigates. Iranian Journal of Biotechnology, 8, 56.

94. Kumar, S. K., Peter, Y. A., \& Nadeau, J. L. (2008b). Facile biosynthesis, separation and conjugation of gold nanoparticles to doxorubicin. Nanotechnology, 19, 4951.

95. Li, G., He, D., Qian, Y., Guan, B., Gao, S., Cui, Y., Yokoyama, K., \& Wang, L. (2012). Fungus-mediated green synthesis of silver nanoparticles using Aspergillus terreus. International Journal of Molecular Sciences, 13, 466.

96. Ingle, A., Gade, A., Pierrat, S., Sonnichsen, C., \& Rai, M. (2008). Mycosynthesis of silver nanoparticles using the fungus Fusarium acuminatum and its activity against some human pathogenic bacteria. Current Nanoscience, 4, 141.

97. Basavaraja, S., Balaji, S. D., Lagashetty, A., Rajasab, A. H., \& Venkataraman, A. (2008). Extracellular biosynthesis of silver nanoparticles using the fungus Fusarium semitectum. Materials Research Bulletin, 43, 1164.

98. Mishra, A. N., Bhadauria, S., Gaur, M. S., \& Pasricha, R. (2010). Extracellular microbial synthesis of gold nanoparticles using fungus Hormoconis resinae. Journal of the Minerals, 62, 48.

99. Shaligram, N. S., Bule, M., Bhambure, R., Singhal, R. S., Singh, S. K., Szakacs, G., \& Pandey, A. (2009). Biosynthesis of silver nanoparticles using aqueous extract from the compactin producing fungal strain. Process Biochemistry, 44, 939.

100. Fayaz, A. M., Balaji, K., Girilal, M., Yadav, R., Kalaichelvan, P. T., \& Venketesan, R. (2010). Biogenic synthesis of silver nanoparticles and their synergistic effect with antibiotics: a study against gram-positive and gram-negative bacteria. Nanomedicine: Nanotechnology, Biology and Medicine, 6, 103.

101. Kannan, B., \& Natarajan, S. (2011b). Facile green synthesis of gold nanostructures by NADPH-dependent enzyme from the extract of Sclerotium rolfsii. Colloids and Surfaces A, 380, 156.

102. Sheikhloo, Z., Salouti, M., \& Katiraee, F. (2011). Biological synthesis of gold nanoparticles by fungus Epicoccum nigrum. Journal of Cluster Science, 22, 661.

103. Gopinath, K., \& Arumugam, A. (2014). Extracellular mycosynthesis of gold nanoparticles using Fusarium solani. Applied Nanoscience, 4, 657.

104. Priyadarshini, E., Pradhan, N., Sukla, L. B., \& Panda, P. K. (2014). Controlled synthesis of gold nanoparticles using Aspergillus terreus IFo and its antibacterial potential against gram negative pathogenic bacteria. Journal of Nanotechnology, 2014, 1.

105. Soni, N., \& Prakash, S. (2012). Synthesis of gold nanoparticles by the fungus Aspergillus niger and its efficacy against mosquito larvae. Reports in Parasitology, 2, 1.

106. Sanghi, R., \& Verma, P. (2010). pH dependant fungal proteins in the 'green' synthesis of gold nanoparticles. Advanced Materials Letters, 1, 193.

107. Saifuddin, N., Wong, C. W., \& Yasumira, A. A. N. (2009). Rapid biosynthesis of silver nanoparticles using culture supernatant of bacteria with microwave irradiation. European Journal of Chemistry, 6, 61.

108. Sintubin, L., Verstraete, W., \& Boon, N. (2012). Biologically produced nanosilver: current state and future perspectives. Biotechnology and Bioengineering, 109, 2422.

109. Vigneshwaran, N., Nachane, R. P., Balasubramanya, R. H., \& Varadarajan, P. V. (2006). A novel one-pot 'green' synthesis of stable silver nanoparticles using soluble starch. Carbohydrate Research, 341, 2012.

110. Bhambure, R., Bule, M., Shaligram, N., Kamat, M., \& Singhal, R. (2009). Extracellular biosynthesis of gold nanoparticles using Aspergillus niger - its characterization and stability. Chemical Engineering \& Technology, 32, 1036.

111. Binupriya, A. R., Sathishkumar, M., \& Yun, S. I. (2010). Biocrystallization of silver and gold ions by inactive cell filtrate of Rhizopus stolonifer. Colloids and Surfaces. B, Biointerfaces, 79, 531.

112. Rada, A. G., Abbasib, H., \& Afzalib, M. H. (2011). Gold nanoparticles: synthesising, characterizing and reviewing novel application in recent years. Physics Procedia, 22, 203.

113. Kannan, B., \& Natarajan, S. (2011a). Synthesis and characterization of nano-gold composite using Cylindrocladium floridanum and its heterogeneous catalysis in the degradation of 4-nitrophenol. Journal of Hazardous Materials, 189, 519.

114. Mishra, A., Tripathy, S. K., \& Yuna, S. (2012). Fungus mediated synthesis of gold nanoparticles and their conjugation with genomic DNA isolated from Escherichia coli and Staphylococcus aureus. Process Biochemistry, 47, 701.

115. Mishra, A., Tripathy, S. K., Wahab, R., Jeong, S., Hwang, I., Yang, Y., Kim, Y., Shin, H., \& Yun, S. (2011). Microbial synthesis of gold nanoparticles using the fungus Penicillium brevicompactum and their cytotoxic effects against mouse mayo blast cancer $\mathrm{C} 2 \mathrm{C} 12$ cells. Applied Microbiology and Biotechnology, 92, 617.

116. Chauhan, A., Zubair, S., Tufail, S., Sherwani, A., Sajid, M., Raman, S. C., Azam, A., \& Owais, M. (2011). Fungus-mediated biological synthesis of gold nanoparticles: potential in detection of liver cancer. International Journal of Nanomedicine, 6, 2305.

117. Oza, G., Pandey, S., Gupta, A., Kesarkar, R., \& Sharon, M. (2012). Biosynthetic reduction of gold ions to gold nanoparticles by Nocardia farcinica. Journal of Microbiology and Biotechnology Research, 2, 511.

118. Das, S. K., Dickinson, C., Lafir, F., Broughamc, D. F., \& Marsili, E. (2012). Synthesis, characterization and catalytic activity of gold nanoparticles biosynthesized with Rhizopus oryzae protein extract. Green Chemistry, 14, 1322.

119. Sheikhloo, Z., \& Salouti, M. (2011). Intracellular biosynthesis of gold nanoparticles by the fungus Penicillium chrysogenum. International Journal of Nanoscience and Nanotechnology, 7, 102.

120. Gericke, M., \& Pinches, A. (2006). Microbial production of gold nanoparticles. Gold Bulletin, 39, 22.

121. Subramanian, M., Alikunhi, M. N., \& Kathiresan, K. (2010). In vitro synthesis of silver nanoparticles by marine yeasts from coastal mangrove sediment. Advanced Science Letters, 3, 428.

122. Lim, H. A., Mishra, A., \& Yun, S. I. (2011). Effect of $\mathrm{pH}$ on the extra cellular synthesis of gold and silver nanoparticles by Saccharomyces cerevisae. Journal of Nanoscience and Nanotechnology, 11, 518.

123. Mishra, A., Tripathy, S., \& Yun, S. (2011b). Bio-synthesis of gold and silver nanoparticles from Candida guilliermondii and their antimicrobial effect against pathogenic bacteria. Journal of Nanoscience and Nanotechnology, 1, 243.

124. Pimprikar, P. S., Joshi, S. S., Kumar, A. R., Zinjarde, S. S., \& Kulkarni, S. K. (2009). Influence of biomass and gold salt concentration on nanoparticle synthesis by the tropical marine yeast Yarrowia lipolytica NCIM 3589. Colloids and Surfaces B: Biointerfaces, 74, 309.

125. Mandal, D., Bolander, M. E., Mukhopadhyay, D., Sarkar, G., \& Mukherjee, P. (2006). The use of microorganisms for the formation of metal nanoparticles and their application. Applied Microbiology and Biotechnology, 69, 485.

126. Magdi, H. M., Mourad, M. H. E., \& El-Aziz, M. M. A. (2014). Biosynthesis of silver nanoparticles using fungi and biological evaluation of mycosynthesized silver nanoparticles. The Egyptian Journal of Experimental Biology (Botany), 10, 1.

127. Kumar, S. A., Peter, Y., Nadeau, J. Biosynthesis, separation and conjugation of gold nanoparticles to doxorubicin for cellular uptake and toxicity. 2009 I.E. 35th Ann. Northeast Bioengg. Conf. 2009. 
128. AL-Kazazz, F. F. M., AL-Imarah, K. A. F., AL-Hasnawi, s. I. A., Agelmashotjafar, L., \& Abdul-Majeed, B. A. (2013). A simple method for synthesis, purification and concentration stabilized gold nanoparticles. Journal of Engineering Research and Applications, 3, 21.

129. Robertson, J. D., Rizzello, L., Milagros, A., Jens, G., Contini, C., Magoń, M. S., Renshaw, S. A., \& Battaglia, G. (2016). Purification of nanoparticles by size and shape. Scientific Reports, 6, 1.

130. Balashanmugam, P., Santhosh, S., Giyaullah, H., Balakumaran, M. D., \& Kalaichelvan, P. T. (2013). Mycosynthesis, characterization and antibacterial activity of silver nanoparticles from Microporus xanthopus: a macromushroom. International Journal of Innovative Research in Science, Engineering and Technology, 2, 6262.

131. Verma, H. N., Singh, P., \& Chavan, R. M. (2014). Gold nanoparticle: synthesis and characterization. Veterinary World, 7, 72.

132. Sunkar, S., \& Nachiyar, C. V. (2012). Microbial synthesis and characterization of silver nanoparticles using endophytic bacterium Bacillus cereus: a novel source in the benign synthesis. Global Journal of Medical Research, 12, 43.

133. Gaikwad, S., \& Bhosale, A. (2012). Green synthesis of silver nanoparticles using Aspergillus niger and its efficacy against human pathogens. European Journal of Experimental Biology, 2, 1654.

134. Sett, A., Gadewar, M., Sharma, P., Deka, M., \& Bora, U. (2016). Green synthesis of gold nanoparticles using aqueous extract of Dillenia indica. Advances in Natural Sciences: Nanoscience and Nanotechnology, 7, 1.

135. Thakker, J. N., Dalwadi, P., \& Dhandhukia, P. C. (2013). Biosynthesis of gold nanoparticles using Fusarium oxysporum $f$. sp. cubense jT1, a plant pathogenic fungi. ISRN Biotechnology, $2013,1$.

136. Srinath, B. S., \& Rai, V. R. (2015). Biosynthesis of gold nanoparticles using extracellular molecules produced by Enterobacter aerogenes and their catalytic study. Journal of Cluster Science, 26, 1483.

137. Shafeev, G. A., Freysz, E., \& Bozon-verduraz, F. (2004). Selfinfluence of a femtosecond laser beam upon ablation of $\mathrm{Ag}$ in liquids. Applied Physics A, 78, 307.
138. Maliszewska, I. (2013). Microbial mediated synthesis of gold nanoparticles: preparation, characterization and cytotoxicity studies. Digest Journal of Nanomaterials and Biostructures, 8, 1123.

139. Shedbalkar, U., Singh, R., Wadhwani, S., Gaidhani, S., \& Chopade, B. A. (2014). Microbial synthesis of gold nanoparticles: current status and future prospects. Advances in Colloid and Interface Science, 209, 40.

140. Sangappa, M., \& Thiagarajan, P. (2012). Mycobiosynthesis and characterization of silver nanoparticles from Aspergillus niger: a soil fungal isolate. International of Journal Life Sciences Biotechnology and Pharma Research, 1, 282.

141. Sharma, N., Pinnaka, A. K., Raje, M., Ashish, F. N. U., Bhattacharyya, M. S., \& Roy Choudhury, A. (2012). Exploitation of marine bacteria for production of gold nanoparticles. Microbial Cell Factories, 11, 86.

142. Barabadi, H., Honary, S., Ebrahimi, P., Mohammadi, M. A., Alizadeh, A., \& Naghibi, F. (2014). Microbial mediated preparation, characterization and optimization of gold nanoparticles. Brazilian Journal of Microbiology, 45, 1493.

143. Awwad, A. M., Salem, N. M., \& Abdeen, A. O. (2013). Green synthesis of silver nanoparticles using carob leaf extract and its antibacterial activity. International Journal of Industrial Chemistry, 4, 29.

144. Shelar, G. B., \& Chavan, A. M. (2014). Fusarium semitectum mediated extracellular synthesis of silver nanoparticles and their antibacterial activity. International Journal of Biomedical and Advance Research, 5, 348.

145. Karthik, C., \& Radha, K. V. (2012). Biosynthesis and characterization of silver nanoparticles using Enterobacter aerogenes: a kinetic approach. Digest Journal of Nanomaterials and Biostructures, 7, 1007.

146. Anuradha, J., Abbasi, T., \& Abbasi, A. (2015). An eco-friendly method of synthesizing gold nanoparticles using an otherwise worthless weed pistia (Pistia stratiotes L.) Journal of Advanced Research, 6, 711.

147. Akbari, B., Tavandashti, M. P., \& Zandrahimi, M. (2011). Particle size characterization of nanoparticles - a practical approach. Iranian Journal Materials Science Engineering, 8, 48.

148. Mohanpuria, P., Rana, N. K., \& Yadav, S. K. (2008). Biosynthesis of nanoparticles: technological concepts and future applications. Journal of Nanoparticle Research, 10, 507. 